Article

\title{
Chemical Composition, Antimicrobial and Antioxidant Activities of Essential Oils from Organically Cultivated Fennel Cultivars
}

\author{
Abdelaaty A. Shahat ${ }^{1}$, Abeer Y. Ibrahim ${ }^{2}$, Saber F. Hendawy ${ }^{2}$, Elsayed A. Omer ${ }^{2}$, \\ Faiza M. Hammouda ${ }^{1}$, Fawzia H. Abdel-Rahman ${ }^{3}$ and Mahmoud A. Saleh ${ }^{4, *}$ \\ 1 Department of Phytochemistry, Production of Medicinal and Aromatic Plants, National Research \\ Centre (NRC), 12311 Dokki, Cairo, Egypt \\ 2 Department of Cultivation, Production of Medicinal and Aromatic Plants, National Research Centre \\ (NRC), 12311 Dokki, Cairo, Egypt \\ 3 Department of Biology, Texas Southern University, 3100 Cleburne Ave, Houston, TX 77004, USA \\ 4 Department of Chemistry, Texas Southern University, 3100 Cleburne Ave, Houston, TX 77004, \\ USA
}

* Author to whom correspondence should be addressed; E-Mail: saleh_ma@tsu.edu; Tel.: +713 3131912; Fax: +7133137824.

Received: 1 December 2010; in revised form: 8 January 2011 / Accepted: 19 January 2011 / Published: 1 February 2011

\begin{abstract}
Essential oils of the fruits of three organically grown cultivars of Egyptian fennel (Foeniculum vulgare var. azoricum, Foeniculum vulgare var. dulce and Foeniculum vulgare var. vulgare) were examined for their chemical constituents, antimicrobial and antioxidant activities. Gas chromatography/mass spectrometry analysis of the essential oils revealed the presence of 18 major monoterpenoids in all three cultivars but their percentage in each oil were greatly different. trans-Anethole, estragole, fenchone and limonene were highly abundant in all of the examined oils. Antioxidant activities of the essential oils were evaluated using the DPPH radical scavenging, lipid peroxidation and metal chelating assays. Essential oils from the azoricum and dulce cultivars were more effective antioxidants than that from the vulgare cultivar. Antimicrobial activities of each oil were measured against two species of fungi, two species of Gram negative and two species of Gram positive bacteria. All three cultivars showed similar antimicrobial activity.
\end{abstract}


Keywords: Foeniculum vulgare var. azoricum; Foeniculum vulgare var. dulce; Foeniculum vulgare var. vulgare; antibacterial; antifungal; antioxidant; organic agriculture; GCMS; DPPH

\section{Introduction}

Foeniculum vulgare Mill. is a biennial medicinal plant belonging to the family Apiaceae (Umbelliferae). Essential oil of fennel is used as flavoring agents in food products such as beverages, bread, pickles, pastries, and cheese. It is also used as a constituent of cosmetic and pharmaceutical products [1]. Herbal drugs and essential oils of fennel have hepatoprotective effects [2], as well as antispasmodic effects [3]. They are also known for their diuretic, anti-inflammatory, analgesic and antioxidant activities [4]. Anand et al [5] reported that fennel seed possesses anticancer activity. Recently it was shown that fennel essential oil possesses emmenagogue and galactagogue properties [6] and is a cure for pediatric colic and respiratory disorders due to its antispasmodic effects $[7,8]$. Many phytochemical studies have been conducted to investigate the chemical composition of the essential oil of fennel from different origins and have shown that the major components are phenylpropanoid derivatives and monoterpenoids [9-11]. Ethnobotanical data currently available on wild useful plants in Egypt highlight the importance of fennel's culinary and medicinal uses [12]. Moreover, fennel has been used for centuries in the Mediterranean area as an aromatic herb and also in folk medicine, due to the aforementioned pharmacological properties of its essential oil.

Essential oil composition depends upon internal, environmental and agricultural practices as well as factors affecting the plant such as genetics, and ecological conditions [13,14]. According to Msaada et al. [15] maturation stages play an important factor influencing essential oil composition, while suitable environmental and agricultural practices would also help in improving yield and quality. Despite records on essential oil composition of fennel fruit [9-11], there are no phytochemical records on chemical composition variation of the three Egyptian fennel cultivars growing in organic farms without the use of pesticides or chemical fertilizers. This research was, therefore, conducted to comparatively examine the chemical composition, antioxidant and antimicrobial activity of the three organically grown fennel cultivars.

\section{Results and Discussion}

\subsection{Chemical analysis}

Quantitative analyses of the chemical composition of the investigated essential oils of the three tested fennel cultivars are shown in Table 1. Gas chromatography/mass spectrometry (GCMS) analysis revealed the presence of 18 major chemicals in all three of the oils. Chemical identification of the oil constituents was conducted based on their retention time $\left(t_{R}\right)$, retention indices $(K I)$ and mass spectral data, as well as by computer search of mass spectral databases. The chemical structures of the 18 identified compounds are shown in Figure 1. Total ion chromatograms of the three tested oils are shown in Figure 2. 
Table 1. Chemical composition of the essential oils of fennel cultivars.

\begin{tabular}{llcccccc}
\hline \multirow{2}{*}{ Name of Compound } & \multicolumn{2}{c}{ CAS \# } & \multirow{2}{*}{$\mathbf{t}_{\mathbf{R}}$} & KI & ID \# & \multicolumn{3}{c}{$\begin{array}{c}\text { Foeniculum vulgare } \\
\text { azoricum }\end{array}$} \\
& & & & & dulce & vulgare \\
\hline$\alpha$-Pinene & $80-56-8$ & 14.56 & 937 & 1 & 1.65 & 3.26 & 3.61 \\
Camphene & $79-92-5$ & 15.25 & 953 & 2 & 0.08 & 0.30 & 0.19 \\
Sabinene & $3387-41-5$ & 16.13 & 973 & 3 & 0.39 & 0.27 & 0.56 \\
$\beta$-Pinene & $127-91-3$ & 16.35 & 981 & 4 & 0.12 & 0.14 & 0.21 \\
Myrcene & $123-35-3$ & 16.72 & 991 & 5 & 0.18 & 0.66 & 0.32 \\
$\alpha$-Phellandrene & $99-83-2$ & 17.43 & 1005 & 6 & 0.11 & 0.18 & 0.11 \\
o-Cymene & $527-84-4$ & 18.13 & 1020 & 7 & 0.46 & 0.38 & 0.71 \\
Limonene & $138-86-3$ & 18.32 & 1034 & 8 & 12.53 & 27.78 & 20.64 \\
Eucalyptol & $470-82-6$ & 18.44 & 1039 & 9 & 2.05 & 0.90 & 1.93 \\
$\gamma$-Terpinene & $99-85-4$ & 19.35 & 1059 & 10 & 0.24 & 0.06 & 0.38 \\
Fenchone & $1195-79-5$ & 20.54 & 1094 & 11 & 7.99 & 12.77 & 7.22 \\
Linalool & $598-07-2$ & 21.73 & 1099 & 12 & 0.29 & 0.09 & 0.11 \\
Camphor & $76-22-2$ & 22.60 & 1143 & 13 & 0.13 & 0.18 & 0.29 \\
Estragole & $140-67-0$ & 24.21 & 1195 & 14 & 11.99 & 6.34 & 57.94 \\
Fenchyl acetate & $4057-31-2$ & 25.25 & 1220 & 15 & 0.13 & 0.06 & 0.21 \\
Cumic aldehyde & $122-03-2$ & 25.92 & 1224 & 16 & 0.18 & 0.06 & 0 \\
$p$-Anisaldehyde & $123-11-5$ & 26.20 & 1252 & 17 & 0.40 & 0.11 & 0.26 \\
trans-Anethole & $4180-23-8$ & 26.96 & 1283 & 18 & 61.11 & 46.26 & 4.99 \\
\hline
\end{tabular}

Figure 1. Chemical structures of the identified compounds from the essential oils with their ID \# as presented in Table 1.

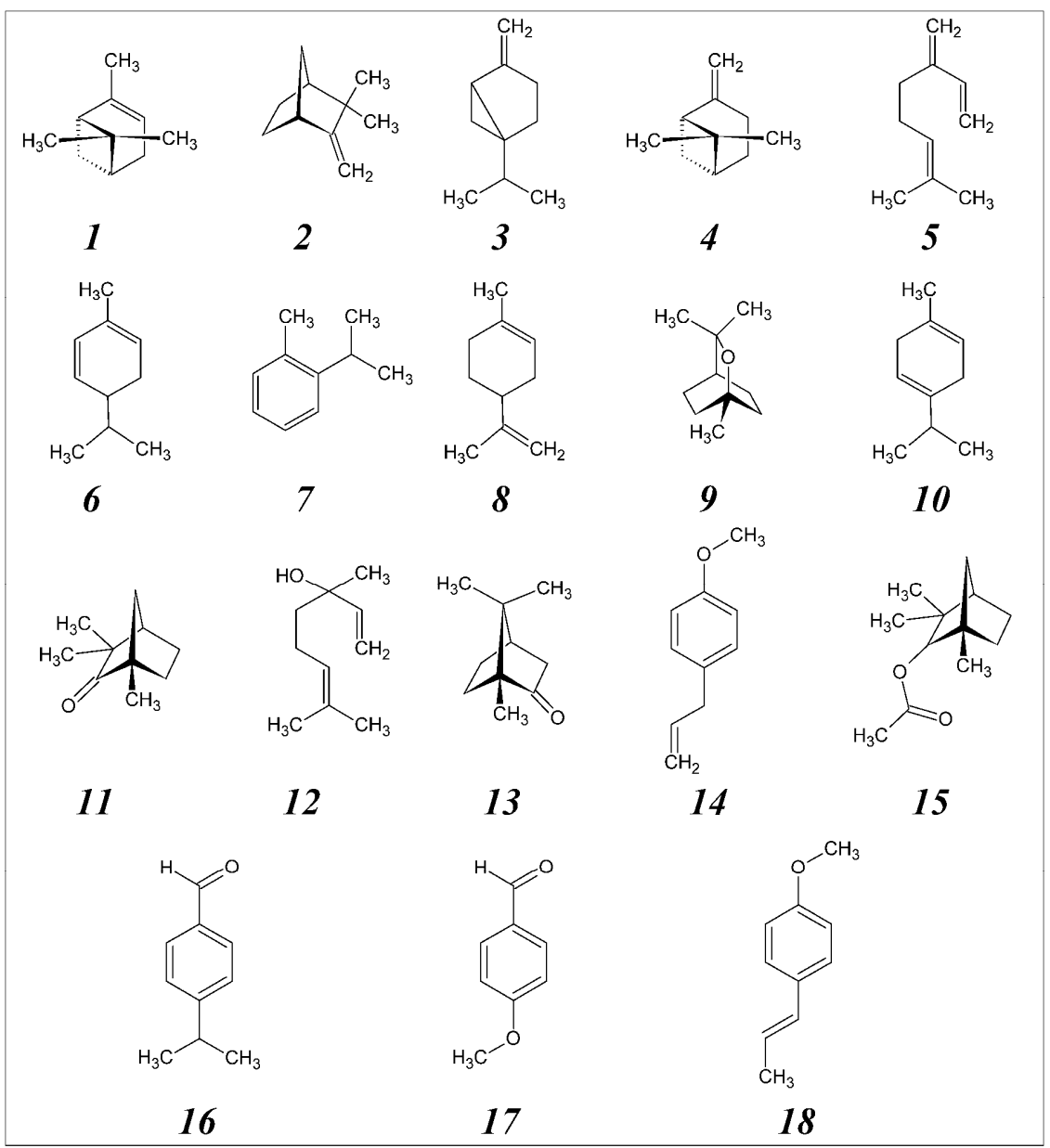


Figure 2. Total ion chromatograms of the three fennel cultivars essential oils.

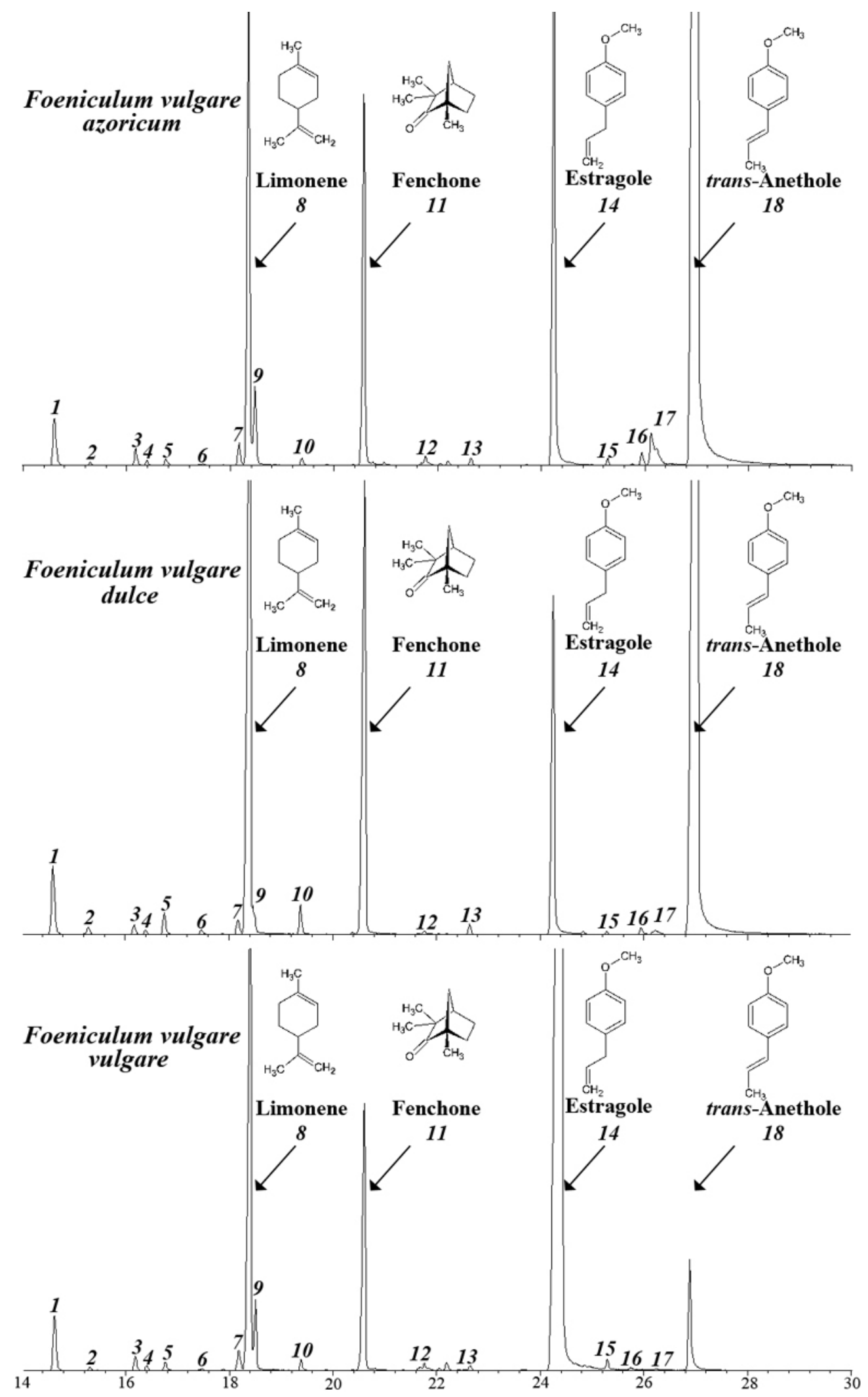

It can be seen from both Table 1 and Figure 2 that the two azoricum and dulce cultivars are similar to some extent in their chemical composition but greatly different than the vulgare cultivar. transAnethole accounted for $61 \%$ and $46 \%$ in the oil of azoricum and dulce cultivars respectively, while it accounted for only $5 \%$ in the vulgare cultivar. On the other hand, estragole was the major compound in 
the oil of the vulgare cultivar, with a concentration of $58 \%$ compared to only $12 \%$ and $6 \%$ in the oils of azoricum and dulce cultivars, respectively. Other major components including pinene, limonene and fenchone were found in all of the three tested oils. Eucalyptol was detected in the azoricum and vulgare cultivars but was absent in the dulce cultivar.

\subsection{Antioxidant activity}

Antioxidant activity of the three essential oils was evaluated by several complementary tests consisting of the DPPH free radical scavenging, the ferric reducing power (FRAP) assay, thiobarbituric acid reactive species assay (TBARS) and the ferrous ion-chelating (FIC) assay, using butylated hydroxytoluene (BHT) and ascorbic acid as references or positive controls. All of the assays were carried out at concentrations of 25,50 and $100 \mathrm{mg} / \mathrm{mL}$ and results were reported as the average of three replicates. The concentrations that inhibited $50 \%$ in each test $\left(\mathrm{IC}_{50}\right.$ values $)$ are shown in Table 2.

Foeniculum vulgare var. azoricum showed the highest activity in quenching of DPPH radical, even higher than either ascorbic acid or BHT. Foeniculum vulgare var. dulce showed compatible scavenging activity to ascorbic acid or BHT. The cultivar Foeniculum vulgare var. vulgare was the least effective radical scavenger, with an $\mathrm{IC}_{50}$ of $15.33 \mathrm{mg} / \mathrm{mL}$ which is about 44 and 37 times higher than the azoricum or dulce cultivars respectively.

Table 2. DPPH free radical scavenging effect of fennel essential oils.

\begin{tabular}{lccc}
\hline Fennel cultivars essential oil and & \multicolumn{3}{c}{ IC $_{\mathbf{5 0}}(\mathbf{m g} / \mathbf{m L})$} \\
\cline { 2 - 4 } tested reference chemicals & DPPH & TBARS & Metal chelating \\
\hline azoricum & 0.35 & 0.08 & 2.23 \\
dulce & 0.41 & 0.03 & 2.51 \\
vulgare & 15.33 & 30.51 & 100.43 \\
Ascorbic acid & 0.40 & 5.89 & 117.11 \\
BHT & 0.44 & 0.002 & 45.15 \\
\hline
\end{tabular}

Similar results were also obtained from the FRAP assay - both azoricum and dulce cultivars were similar in their antioxidant activity to ascorbic acid and BHT, however, the activity of the cultivar vulgare was much lower. In the TBARS assay the essential oil from the different Foeniculum vulgare cultivars showed inhibitory activity against lipid peroxidation with $\mathrm{IC}_{50}$ values of $0.08,0.03$ and $30.51 \mathrm{mg} / \mathrm{mL}$, for the azoricum, dulce and vulgare cultivars, respectively (Table 2). Foeniculum vulgare azoricum at $100 \mathrm{mg} / \mathrm{mL}$ showed approximately the same activity as BHT, but slightly higher than ascorbic acid in inhibition of lipid peroxidation. Formation of the $\mathrm{Fe}^{2+}$ complex did not reach completion in the presence of the fennel essential oils, indicating that essential oil chelates the iron. The metal chelating scavenging effect of fennel oils and standards decreased in the order of azoricum $>$ dulce $>$ BHA $>$ ascorbic acid $>$ vulgare. The data in Table 2 reveals that azoricum fennel has a remarkable capacity for iron binding, suggesting that is action as peroxidation protector may be related to its iron binding capacity. Based on the data obtained from this study, fennel essential oil exhibits ability as a free radical inhibitor or scavenging activity as well as primary antioxidant that reacts with free radicals, which may limit free radicals damage occurring in the human body. 


\subsection{Antimicrobial activity}

Antimicrobial activity of the essential oils obtained from the three fennel cultivars are shown in Table 3. Ampicillin was used as a reference material or positive control for the antibacterial activity and clotrimazole was used as a reference or positive control for the antifungal activity. The results indicated that all essential oil samples have antibacterial activity against Gram negative and Gram positive bacteria. The most effective oil against Gram negative bacteria was Foeniculum vulgare azoricum, which is less effective than ampicillin by $25 \%$ and $7 \%$ in the Escherichia coli and Psedumonas aeruginosa bioassays, respectively, while the most effective essential oil against Gram positive bacteria was Foeniculum vulgare vulgare which gave a larger inhibition zone than ampicillin by $58.3 \%$ and $114 \%$ in the Staphylococcus aureus and Bacillus subtilis tests, respectively. These data coincide with those of LoCantore et al. [16] who reported that fennel essential oil displayed a significant antibacterial activity, as determined with the agar diffusion method. The results also showed that Foeniculum vulgare azoricum was more effective antifungal than that of the reference commercial fungicidal clotrimazole. It produced $46 \%$ more inhibition (inhibition zone in $\mathrm{mm}$ ) compared to the standard drug for Aspergillus niger, and it also has the same high activity against yeast, forming an inhibition zone larger than that of the standard drug by $40 \%$. In conclusion, the essential oil of the three cultivars have antimicrobial activities and potent activity was observed with the azoricum variety in most cases, while vulgare cultivar is the most effective against Gram positive bacteria.

Table 3. Antimicrobial activity of different fennel cultivars determined by disc diffusion assay.

\begin{tabular}{|c|c|c|c|c|c|c|}
\hline \multirow{4}{*}{$\begin{array}{c}\text { Cultivars Oils } \\
\text { and } \\
\text { Reference } \\
\text { Chemicals }\end{array}$} & \multicolumn{6}{|c|}{ Diameter of inhibition zone in $\mathrm{mm}$} \\
\hline & \multicolumn{4}{|c|}{ Bacteria } & \multirow{2}{*}{\multicolumn{2}{|c|}{ Fungi }} \\
\hline & \multicolumn{2}{|c|}{ Gram Negative } & \multicolumn{2}{|c|}{ Gram Positive } & & \\
\hline & $\begin{array}{l}\text { Escherichia } \\
\text { coli }\end{array}$ & $\begin{array}{l}\text { Pseudomonas } \\
\text { aeruginosa }\end{array}$ & $\begin{array}{c}\text { Staphylococcus } \\
\text { aureus }\end{array}$ & $\begin{array}{l}\text { Bacillus } \\
\text { subtilis }\end{array}$ & $\begin{array}{l}\text { Aspergillus } \\
\text { niger }\end{array}$ & $\begin{array}{l}\text { Candida } \\
\text { albicans }\end{array}$ \\
\hline azoricum & 15.0 & 13.0 & 14.0 & 15.0 & 19.0 & 21.0 \\
\hline dulce & 9.0 & 12.0 & 15.0 & 13.0 & 18.0 & 16.0 \\
\hline vulgare & 11.0 & 12.0 & 19.0 & 15.0 & 16.0 & 19.0 \\
\hline Ampicillin & 20.0 & 14.0 & 12.0 & 7.0 & - & - \\
\hline Clotrimazole & - & - & - & - & 13.0 & 15.0 \\
\hline
\end{tabular}

These recorded activities are in accordance with Khaldun [17], who reported that fennel oil had high antibacterial effect on Candida albicans, and bactericidal action on Salmonella typhimurium and Salmonella dysenteriae. Ozcan [18] also concluded that, the oils exerted varying levels of antifungal effects on the experimental mycelia growth of Alternaria alternata, Fusarium oxysporum, and Rhizoctonia solani.

\section{Experimental}

\subsection{Organic farming}

Seeds of the three cultivars were obtained from the SEKEM Company of Egypt (3 Cairo-Belbeis Desert Road, El-Horreya, Cairo, Egypt). The soil was prepared for cultivation by adding $20 \mathrm{~m}^{3}$ 
compost, $200 \mathrm{Kg}$ rock phosphate, $100 \mathrm{Kg}$ feldspar to the soil on October 5, 2008 then irrigated to push weeds for growing up as well as plowing in rectangular way is required then establishing the rows via tractors. Seeds were manually sown on October 23, 2008 in lines which contain two irrigation dropping lines with $30 \mathrm{~cm}$ distance in between hoses. After sowing, seeds received a rich irrigation. The first process of weeding was carried out after the complete germination of seeds on November 4 , 2008. Another process was done after thinning the seedlings to be two seedlings only in each hole (when the plant reached $8 \mathrm{~cm}$ in length). Four $\mathrm{m}^{3}$ of compost per feddan $\left(4,200 \mathrm{~m}^{2}\right)$ was added as organic fertilizer. The same kind of organic fertilizer was added at the rate of $4 \mathrm{~m}^{3} /$ feddan during the third weeding. The first flowering was on February 02, 2009 and the harvest processes were conducted in May 23, 2009 by hands in the morning to avoid fruits escaping. Then moved to a clean drying location in the shade for seven to ten days for the separation of the fruits. The productivity per feddan was $800 \mathrm{Kg}$ of fruits for azoricum and dulce and 1,200 kg for vulgare.

\subsection{Isolation of essential oils}

Fresh fennel fruits were dried at $35{ }^{\circ} \mathrm{C}$ in a drying cabinet and crushed to powders using a grinder. Essential oil was obtained by hydrodistillation of the powdered dry fruits according to the British Pharmacopeia Protocol [19]. The oil phase was separated, dried over anhydrous sodium sulfate, and kept in a dark glass bottle at $4{ }^{\circ} \mathrm{C}$ until the analyses.

\subsection{Gas chromatography/mass spectrometry (GC/MS) analysis}

GC/MS analysis of the essential oil was carried out using an HP5890 Series II Gas Chromatograph, HP 5972 Mass Selective Detector and Agilent 6890 Series Autosampler (Agilent Technologies, USA). A Supelco MDN-5S $30 \mathrm{~m} \times 0.25 \mathrm{~mm}$ capillary column with a $0.5 \mu \mathrm{m}$ film thickness was used with helium as the carrier gas at a flow rate of $1.0 \mathrm{~mL} / \mathrm{min}$. The $\mathrm{GC}$ oven temperature was programmed at an initial temperature of $40^{\circ} \mathrm{C}$ for 5 minutes, then heated up to $140{ }^{\circ} \mathrm{C}$ at $5{ }^{\circ} \mathrm{C} / \mathrm{min}$ and held at $140{ }^{\circ} \mathrm{C}$ for $5 \mathrm{~min}$, then heated to $280{ }^{\circ} \mathrm{C}$ at $9{ }^{\circ} \mathrm{C} / \mathrm{min}$ and held for five additional minutes. Injector and detector temperatures were set at $250{ }^{\circ} \mathrm{C}$. Mass spectrometry was run in the electron impact mode (EI) at $70 \mathrm{eV}$. The identification of the chemical constituents of the oil was determined by their GC retention times, retention indices and interpretation of their mass spectra and confirmed by mass spectral library search using the National Institute of Standards and Technology (NIST) database with those of authentic samples or published data [20]. The retention indices were calculated for all of the volatile constituents using a homologous series of $\mathrm{C}_{8}-\mathrm{C}_{20} n$-alkanes.

\subsection{DPPH radical-scavenging activity}

The antioxidant activity was determined using DPPH (1,1-diphenyl-2-picrylhydrazyl) radical scavenging model [21]. Three concentrations of tested essential oils $(25,50$ and $100 \mu \mathrm{g} / \mathrm{mL})$ prepared in methanol having a final DPPH radical concentration of $0.1 \mathrm{mM}$. The mixture was shaken vigorously $(2,500 \mathrm{rpm})$ for $1 \mathrm{~min}$ then left to stand for $60 \mathrm{~min}$ in the dark. Scavenging capacity was measured spectrophotometrically at $517 \mathrm{~nm}$. Ascorbic acid was used as a positive control. Inhibition (\%) was plotted against the sample concentration in the reaction system. The percentage inhibition of the DPPH radical calculated according to the following formula: 


$$
\% \text { Inhibition }=\left[\left(\mathrm{A}_{\text {control }}-\mathrm{A}_{\text {sample }}\right) / \mathrm{A}_{\text {control }}\right] \times 100
$$

where $\mathrm{A}$ is absorbance.

\subsection{Ferric reducing antioxidant power (FRAP)}

The ferric reducing power of the essential oils was determined by using the potassium ferricyanideferric chloride method [11]. Different concentrations of three essential oils $(25,50$ and $100 \mu \mathrm{g} / \mathrm{mL})$ were added to $2.5 \mathrm{~mL}$ phosphate buffer $(0.2 \mathrm{M}$, pH 6.6) and $2.5 \mathrm{~mL}$ potassium ferricyanide (1\%). The mixtures were incubated at $50{ }^{\circ} \mathrm{C}$ for $20 \mathrm{~min}$, after which $2.5 \mathrm{~mL}$ trichloroacetic acid (10\%) was added. An aliquot of the mixture $(2.5 \mathrm{~mL})$ was taken and mixed with $2.5 \mathrm{~mL}$ water and $0.5 \mathrm{~mL} 1 \%$ $\mathrm{FeCl}_{3}$. The absorbance at $700 \mathrm{~nm}$ was measured after allowing the solution to stand for $30 \mathrm{~min}$. The FRAP of a sample is estimated in terms of Trolox equivalent antioxidant capacity (TEAC) in mM/L Trolox. Each assay was carried out in triplicate. Higher absorbance of the reaction mixture indicated greater reducing power.

\subsection{Thiobarbituric acid reactive species test (TBARS)}

The method of Daker et al. [22] was used to determine the thiobarbituric acid reactive substance (TBARS) [23], a secondary product of lipid peroxidation. For this, $0.1 \mathrm{~mL}$ of different dilutions of essential oils $(25,50$ and $100 \mathrm{mg} / \mathrm{mL})$ was added to mixture that contained $1 \mathrm{~mL}$ fowl egg yolk emulsified with $0.1 \mathrm{M}$ phosphate buffer, $\mathrm{pH} 7.4$, to obtain a final concentration of $25 \mathrm{~g} / \mathrm{L}$ and $100 \mu \mathrm{L}$ of $1 \mathrm{mM} \mathrm{Fe}^{2+}$. The mixture was incubated at $37{ }^{\circ} \mathrm{C}$ for $1 \mathrm{~h}$, after which it was treated with $0.5 \mathrm{~mL}$ freshly prepared $15 \%$ trichloroacetic acid (TCA) and $1 \mathrm{~mL} 1 \%$ thiobarbituric acid (TBA). The reaction tubes were kept in a boiling water bath for $10 \mathrm{~min}$. Upon cooling with ice, the tubes were centrifuged at 3,500 rpm for $10 \mathrm{~min}$ to remove precipitated protein. The formation of TBARS was measured by removing $100 \mu \mathrm{l}$ supernatant and measuring the absorbance at $532 \mathrm{~nm}$. The control was buffered egg yolk with $\mathrm{Fe}^{2+}$ only. Butylated hydroxyl toluene (BHT) and ascorbic acid were used as the standards. The percentage inhibition ratio was calculated from the following equation:

$$
\% \text { Inhibition }=\left[\left(\mathrm{A}_{\text {control }}-\mathrm{A}_{\text {sample }}\right) / \mathrm{A}_{\text {control }}\right] \times 100
$$

where $\mathrm{A}=$ absorbance

The concentration needed to achieve 50\% inhibition $\left(\mathrm{IC}_{50}\right)$ was determined by plotting the percentage of lipid peroxidation inhibition against essential oil concentrations. Each assay was carried out in triplicate.

\subsection{Ferrous ion chelating ability assay}

The ferrous ion-chelating (FIC) assay was carried out according to the method of Singh and Rajini [24]. Solutions of $2 \mathrm{mM} \mathrm{FeCl}_{2} \cdot 4 \mathrm{H}_{2} \mathrm{O}$ and $5 \mathrm{mM}$ ferrozine were diluted 20 times. Briefly, an aliquot $(1 \mathrm{~mL})$ of different concentrations of essential oils $(25,50$ and $100 \mathrm{mg} / \mathrm{mL})$ was mixed with $1 \mathrm{~mL}$ $\mathrm{FeCl}_{2} \cdot 4 \mathrm{H}_{2} \mathrm{O}$. After $5 \mathrm{~min}$ incubation, the reaction was initiated by the addition of ferrozine $(1 \mathrm{~mL})$. The mixture was shaken vigorously and after a further $10 \mathrm{~min}$ incubation period the absorbance of the solution was measured spectrophotometrically at $562 \mathrm{~nm}$. The percentage inhibition of ferrous $\mathrm{Fe}^{+2}$ complex formation was calculated by using the formula: 


$$
\% \text { Inhibition }=\left[\left(\mathrm{A}_{\text {control }}-\mathrm{A}_{\text {sample }}\right) / \mathrm{A}_{\text {control }}\right] \mathrm{X} 100
$$

where $\mathrm{A}=$ absorbance

\subsection{Antimicrobial activity}

\subsubsection{Tested microorganisms}

For the purpose of antimicrobial evaluation of the fennel cultivars essential oils, six microorganisms were used. Four bacterial species, Pseudomonas aeruginosa (Gram-negative), Escherichia coli (Gramnegative), Staphylococcus aureus (Gram-positive), Bacillus subtilis (Gram-positive), and two fungal species, Aspergillus niger and Candida albicans were employed for the determination of the antimicrobial activity. Bacteria and fungi were obtained from the stock cultures of Microbiology Laboratory at the National Research Centre in Giza, Egypt.

\subsubsection{Antimicrobial activity determination}

To determine the antimicrobial activities of each tested essential oil, the disk diffusion method was utilized [25]. Using cultures of Escerichia coli, Psedumonas aeruginosa, Staphylococcus aureus, Bacillus subtilis, Aspergillus niger, and Candida albicans; bacterial species were cultured on nutrient agar media, while fungi were cultured on malt and yeast extract media. Inoculum suspension $\left(10^{4} \mathrm{CFU} \mathrm{mL} \mathrm{m}^{-1}\right)$ was prepared from each microorganism in broth media, nutrient broth inoculated with each bacterial species was incubated for $24 \mathrm{~h}$ at $37^{\circ} \mathrm{C}$; and malt and yeast extract broth with each fungal species were incubated for $48 \mathrm{~h}$ at $35^{\circ} \mathrm{C}$. Sterile filter paper disks (6.3 mm in diameter) were impregnated with $10 \mu \mathrm{L}$ of each tested essential oil. The disks were allowed to dry at room temperature in a sterile airflow laminar chamber for one hour, then they were placed in the center of fresh nutrient agar plates or malt and yeast extract agar plates previously seeded with $100 \mu \mathrm{L}$ of inoculum suspension of each bacterial and fungal species respectively. The cultures were incubated either at $35^{\circ} \mathrm{C}$ for $72 \mathrm{~h}$ for filamentous fungus or at $37^{\circ} \mathrm{C}$ for $24-48 \mathrm{~h}$ for yeasts and bacteria. Each experiment was replicated three times. Antibiotics were used as positive control; ampicillin was used as antibacterial standard, while miconazole nitrate was used as antifungal standard. The antimicrobial activities were evaluated by measuring the inhibition zone diameters (millimeters) surrounding each disk.

\subsection{Statistical analysis}

Conventional statistical methods were used to calculate means and standard deviations of three simultaneous assays carried out with the different methods. Analysis of variance (ANOVA) was applied to the data to determine differences $(p<0.05)$. To discover if there were significant differences between the levels of the main factor, contrasts (Tukey's test) between means were made. [26] For the antioxidant activity, ANOVAs with two factors (essential oil and concentration) were applied for each parameter. The statistical analyses were made using Statgraphics 5.1 for Windows. A correlation between total phenols and antioxidant capacity was made using the function CORREL from Microsoft Excel software. 


\section{Conclusions}

The essential oils of two of the fennel cultivars, i.e. azoricum and dulce, showed dramatically higher antioxidant activities than the essential oil of the vulgare cultivar. The two oils were similar in that trans-anethole was the major component in each oil, reaching $61 \%$ and $46 \%$ of the total oil of azoricum and dulce, respectively. On the other hand the essential oil of the vulgare cultivar contains only $5 \%$ trans-anethole and $58 \%$ estragole, which was only found at $12 \%$ and $6 \%$ in the other two cultivars. The fact that all of the three oils contain similar concentrations of all other major compounds excluding trans-anethole and estragole suggests that antioxidant activity is mostly related to the concentration of trans-anethole. One of the major differences between the chemical structure of estragole and anethole is the double bond of the propenyl side chain in anethole is conjugated with the aromatic ring while in estragole it is nonconjugated. trans-anethole can easily form a conjugated radical cation that can be easily delocalized with the aromatic ring and further stabilized by the methoxy group through the 1, 4 interaction in contrast to estragole which can only form homobenzyllic radical cation as shown in Figure 3.

Figure 3. Radicals intermediates from anethole and estragole.

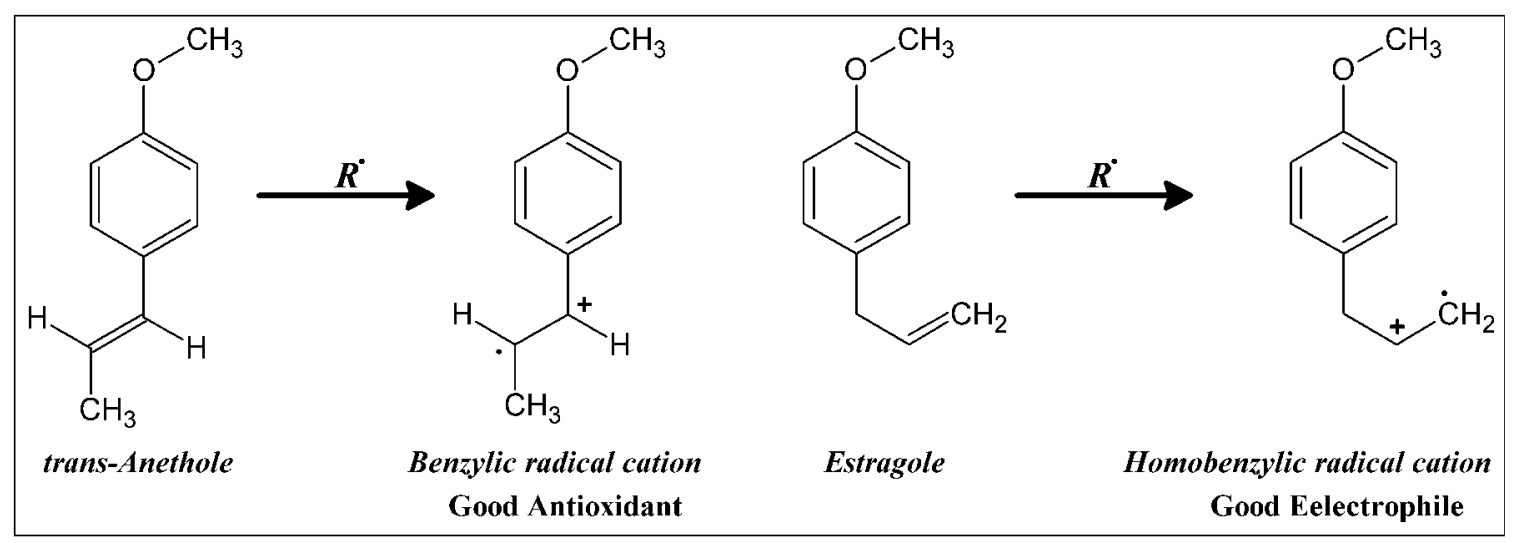

This difference between anethole and estragole was also observed in their free radical and photochemical dimerizations in which anethole dimerized by forming the intermediate radical cation but not estragole [27,28]. This observation may explain the differences in the antioxidant activity between the tested essential oils. It can also be concluded that anethole is a good radical scavenger but estragole is a good alkylation agent which might explain that estragole can easily alkylate DNA molecules and therefore, are suspected carcinogen as indicated by its ability to form covalent bonds with DNA bases [29].

Antimicrobial activities were similar among the three tested essential oils indicating that the antimicrobial effect of the oils is not related to radical interaction and both estragole and anethole are similar in their antimicrobial effects.

\section{Acknowledgements}

This work is partially supported by STDF, Egyptian Academy of Scientific Research and Technology "ID\# 245" and by the National Institutes of Health (NIH) USA, Grant \# RCMI-R003045. 


\section{References}

1. Piccaglia, R.; Marotti, M. Characterization of Some Italian Types of Wild Fennel (Foeniculum vulgare Mill.) J. Agric. Food Chem. 2001, 49, 239-244.

2. Ozbek, H.; Ugras, S.; Dulger, H.; Bayram, I.; Tuncer, I.; Ozturk, G. Hepatoprotective effect of Foeniculum vulgare essential oil. Fitoterapia 2003, 74, 317-319.

3. Reynolds, J.E.F. Essential Oils and Aromatic Carminatives, Martindale-The Extra. Pharmacopeia 1982, 670-676.

4. Choi, E.; Hwang, J. Antiinflammatory analgesic and antioxidant activities of the fruit of Foeniculum vulgare. Fitoterapia 2004, 75, 557-565.

5. Anand, P.; Kunnumakara, A.; Sundaram, C.; Harikumar, K.; Tharakan, S.; Lai, O.; Sung, B.; Aggarwal, B. Cancer is a preventable disease that requires major lifestyle changes. Pharmaceut. Res. 2008, 25, 2097-2116.

6. Babu, R.V.; Kim, C.; Kim, S.; Ahn, C.; Lee, Y.I. Development of semi interpenetrating carbohydrate polymeric hydrogels embedded silver nanoparticles and its facile studies on $E$. coli. Carbohydr. Polym. 2010, 81, 196-202.

7. Liu, J.; Luo, J.G,; Ye, H.; Sun, Y.; Lu, Z.X.; Zeng, X.X. Medium optimization and structural characterization of exopolysaccharides from endophytic bacterium Paenibacillus polymyxa EJS-3. Carbohydr. Polym. 2010, 79, 206-213.

8. Sajomsang, W.; Gonil, P.; Tantayanon, S. Antibacterial activity of quaternary ammonium chitosan containing mono or disaccharide moieties: Preparation and characterization. Int.J. Biol. Macromolecules 2009, 44, 419-427.

9. Renjie, L.; Zhenhong, L.; Shidi, S. GC-MS analysis of fennel essential oil and its effect on microbiology growth in rats' intestine. Afr. J. Microbiol. Res. 2010, 4, 1319-1323.

10. Diaz-Maroto, M.S.; Perez-Coello, S.; Esteban, J.; Sanz, J. Comparison of the volatile composition of wild fennel samples (Foeniculum vulgare Mill.) from Central Spain. J. Agric. Food Chem. 2006, 54, 6814-6818.

11. Ozcan, M.M.; Chalchat, J.C.; Arslan, D.; Ate, A.; Unver, A. Comparative essential oil composition and antifungal effect of bitter fennel (Foeniculum vulgare ssp. piperitum) fruit oils obtained during different vegetation. J. Med. Food 2006, 9, 552-561.

12. Singh, B.; Kale, R.K. Chemomodulatory action of Foeniculum vulgare (Fennel) on skin and forestomach papillomagenesis, enzymes associated with xenobiotic metabolism and antioxidant status in murine model system. Food Chem. Toxicol. 2008, 46, 3842-3850.

13. Telci, I.; Toncer, O.G.; Sahbaz, N. Yield, Essential oil content and composition of Coriandrum sativum cultivars (var. vulgare Alef. and var. microcarpum DC.) grown in two different locations. J. Essent. Oil Res. 2006, 18, 189-193.

14. Fuente, E.B.; Gil, A.; Lenardis, A.E.; Pereira, M.L.; Suarez, S.A.; Ghersa, C.M.; Grass, M.Y. Response of winter crops differing in grain yield and essential oil production to some agronomic practices and environmental gradient in the Rolling Pampa. Argentina. Agr. Ecosyst. Environ. 2003, 99, 59-169. 
15. Msaada, K.; Hosni, K.; Taarit, M.B.; Chahed, T.; Kchouk, M.E.; Marzouk, M. Changes on essential oil composition of coriander (Coriandrum sativum L.) fruits during three stages of maturity. Food Chem. 2007, 102, 1131-1134.

16. LoCantore, P.; Iacobellis, N.S.; De Marco, A.; Capasso, F.; Senatore, F. Antibacterial activity of Coriandrum sativum L. and Foeniculum vulgare Miller var. vulgare (Miller) essential oils. $J$ Agric. Food Chem. 2004, 52, 7862-7866.

17. Khaldun, A.O. Antibacterial action of ether oils of some plants. Zh Mikrobiol Epidemiol Immunobiol. 2006, 3, 92-93.

18. Adam, K.; Sivropoulu, A.; Kokkini, S.; Lanaras, T.; Arsenakis, M. Antifungal activities of Origanum vulgare subsp. hirtum, Mentha spicata, Lavandula angustifolia and Salvia fruticosa essential oils against human pathogenic fungi. J. Agr. Food Chem. 1998, 46, 1739-1745.

19. British Pharmacopeia, Appendix XI F; HMSO: London, UK, 1988; Volume 2, p. A138.

20. Adams, R.P. Identification of Essential Oil Components by Gas Chromatography/Mass Spectrometry; Allured Publishing: Carol Stream, IL, USA, 2007.

21. Mahakunakorn, P.; Tohda, M.; Murakami, Y.; Matsumoto, K.; Watanabe, H. Antioxidant and free radical-scavenging activity of Choto-san and its related constituents. Biol Pharm Bull 2004, 27, $38-46$.

22. Daker, M.N.; Abdullah, S.; Vikineswary, P.C.; Goh, U.R.; Kuppusamy. Antioxidant from maize and maize fermented by Marasmiellus sp. as stabilizer of lipid-rich foods. Food Chem. 2008, 107, 1092-1098.

23. Viuda-Martos, M.; Navajas, Y.; Zapata, E.S. Juana; López, F.; Pérez-Álvarez, J.A. Antioxidant activity of essential oils of five spice plants widely used in a Mediterranean diet. Flavour Frag. J. 2010, 25, 13-19.

24. Singh, N.; Rajini, P.S. Free radical scavenging activity of an aqueous extract of potato peel. Food Chem. 2004, 85, 611-616.

25. Sisti, M.; DeSanti, M.; Fraternale, D.; Ninfali, P.; Scoccianti, V.; Brandi, G. Antifungal activity of Rubus ulmifolius Schott standardized in vitro culture. LWT 2008,41, 946-950.

26. Bland, J.M.; Altman, D.G. Multiple significance tests: the Bonferroni method. Br. Med. J. 1995, 310, 170.

27. Meyer, S.; Koch, R.; Metzger, J.O. Investigation of reactive intermediates of chemical reactions in solution by electrospray ionization mass spectrometry: Radical cation chain reactions. Angew. Chem. Int. Ed. 2003, 42, 4700-4703.

28. Yamaok, R.; Tsujino, T.S.; Kimura, Y.; Ohta, M. Detection of organic free radicals in irradiated Foeniculi fructus by electron spin resonance spectroscopy, J. Nat. Med. 2009, 63, 28-31.

29. McDonald, T.A. Evidence on the carcinogenicity of estragole. Reproductive and Cancer Hazard Assessment Section Office of Environmental Health Hazard Assessment California Environmental Protection Agency: Sacramento, California, USA, 1999.

Sample Availability: Samples of the essential oils are available from the authors.

(C) 2011 by the authors; licensee MDPI, Basel, Switzerland. This article is an open access article distributed under the terms and conditions of the Creative Commons Attribution license (http://creativecommons.org/licenses/by/3.0/). 